On the evening of May 21st I saw the father, who asked me to call on the following day, which I did, and was much surprised to find the child in a very serious condition. The lnngs were in a terrible state. Nothing could be done for the suffering mite. I attended every day, doing my best to relieve the child, but he gradually grew worse and on May $29 \mathrm{th}$, while on my rounds, I was met and asked to see the little patient at once as he was vomiting blood. I accordingly hurried to the house, only to be met with the cry that the child was in a neighbour's house. The mother, when she saw the blood, screamed, and ran and threw the baby into the lap of a neighbour. The child had given a very slight cough, when blood began to flow from mouth and nose. He vomited three times within the hour, in all about 3 to 4 ounces. There was no blood vomited from 12 noon to 4 A.M. on the 30th, when vomiting again commenced, the vomit being only coloured with blood at the time. About 930 A.M. he had another attack of vomiting, about one ounce of blood at this time. There was no more vomiting till $12.50 \mathrm{P} \mathrm{M}$., when he vomited about three drachms of blood with fatal result. Treatment was confined to staying the blood if possible, cold water, ice, with adrenalin and ergot. There was no necropsy.

Can any of your readers let me know how frequently hæmoptysis occurs in so young a child?

I am, Sir, yours faithfully,

Gatehouse of Fleet.

P. Carruthers WatT, L.R.C.P. Edin., \&c.

\section{THE DETERMINING FACTOR IN SEX.}

\section{To the Editor of THE LANCET.}

SIR,-Professor Ciesielski of Lwow has after 30 years' hesitation published a short pamphlet in Latin giving the result of experiments in the production of sex. He is a botanist, and his initial experiments were on plants. Naturally a diœcious plant had to be employed; most diœcious plants produce occasional staminal flowers on female individuals, but such a "sport" occurs with extreme rarity in Cannabis sativa, and accordingly this species was chosen for experiments. Professor Ciesielski concluded, as far back as 1878, that the determining factor is the freshness or otherwise of the pollen cell. His first conclusive experiment gave 94.6 per cent. of male plants in the case of artificial impregnation with pollen from an anther which was just dehiscing, and 100 per cent. of female plants when the pollen had been kept some 12 hours before use. The experiment was several times repeated with similar results.

He thereafter investigated the question in the animal kingdom. The conditions of experiment being less fully under the control of the investigator, the results are not so striking, but they are numerous enough and consistent enough to deserve attention. His statement of the law governing sex is as follows:-

Pari modo in animalibus et hominıbus destinari tantum zoospermiis sexum orituri fetus. Zoospermia enim recentiora (i.e., ducentia originem ex ejaculatione spermatis masculini, quae fit ante decursum spatii unius diei ab antecedente coitu) producere fetum masculum, zoospermia autem vetustiora (quae ejaculata sint post longius spatium quam unins diei ab antecedente coitu) prodere fetum femineum.

He made experiments in rabbits, in dogs, horses, and cattle. Of these the first two were not very striking; but he declares that careful analysis of the stud record of a stallion showed that the rule held generally in regard to female foals and invariably in the case of male foals. With a stud bull under the control of an intelligent and careful servant of his own he found only two exceptions to his rule in 156 cases, and he believes these to be only apparent exceptions.

Denique non est silentio præetereundum, mihi per triginta tres annos sæpius potestatem ejus legis in hominibus probandæ non defuisse, consultus enim a multis meis cognatis, amicis, familiaribus præcepta eventus habebant.

Many investigators have kelieved they had solved this problem; very few, one fancies, have maintained a firm belief in their solution for 30 years, and yet not published it. Professor Ciesielski deliberately kept his solution to himself, "verebar enim, ne cognita ad depravandos rectos mores conferret," and has now deliberately enshrined it in this brief Latin pamphlet of 15 pages. The law is so simple, depending on a single factor, and is stated so definitely by him, that confirmation or disproof of its truth ought to be obtained without much difficulty by other observers.

I am, Sirs, yours faithfully,

Norwood, Jan. 22nd, 1912, S. W. CARruthers, M.D. Edin.

\section{THE MORBID DIATHESES.}

\section{To the Editor of THE LANCET.}

SIR,-_Sir Dyce Duckworth has done good service in drawing attention to this now unfashionable but vitally important subject; perhaps you will allow me slightly to elaborate it. The "constitution" includes all the intrinsic tendencies, normal and morbid, of the individual ; a "morbid diathesis" is a particular, recognisable constitutional defect. These morbid diatheses, or constitutional defects, are just as effective in causing symptoms of disease as are microbes, and far more ubiquitous. If we consider four individual patients, a diabetic child, an asthmatic man, a hysterical young woman, and a bonâ fide chronic lunatic, it will be acknowledged, even by surgeons and bacteriologists, that the symptom-groups shown are not due to any "extraneous influence," to any extrinsic cause. In these and many other cases the symptoms are due to a morbid diathesis, to a canse of purely intrinsic origin.

Gach of these patients is an example from a series of cases, a "known series" in our science. From each such series we may, if we will, derive a conception that will in each case represent a true disease. "The diseases" diabetes, asthma, hysteria, insanity, would thus become "diseases of intrinsic causation." They would correspond with, for instance, typhoid fever, lead poisoning, and heat-stroke, these latter being conceptional diseases of extrinsic causa tion. It will no doubt interest Mr. Clement Lucas to hear that his old friend Dr. Walter Moxon said, in his introductory lecture in 1884: "The causes of disease have been divided in the past into predisposing and exciting; they will be divided in the future into intrinsic and extrinsic." Dr. Moxon was before his time, but he was no false prophet. I am, Sir, yours faithfully,

Clevedon, Jan. 22nd, 1912. SydNEY W. MacILWAINE.

\section{THE ADMISSION OF VENEREAL CASES TO GENERAL HOSPITALS. \\ To the Editor of THE LANCET.}

SIR, - In the paper on Venereal Diseases ${ }^{1}$ by Dr. D. White and Lieutenant-Colonel C. H. Melville it is suggested that patients suffering from them should be admitted to general hospitals, that special arrangements and wards should be provided for these cases, and a special course of instruction should be given to the medical staff as to the diseases and their treatment at the State expense. The nursing, however, has not been considered, and a special staff of trained male and female nurses would have to be provided and maintained. The need for male nurses for such male patients needs no demonstrating, especially in the hospitals without medical schools, where there are no dressers to give injections and to do the dressings, unless the patients are to carry out the local treatment themselves.

A well-paid staff of trained women would also be requ red, for it would not be justifiable to force young probationers to nurse in the venereal wards as part of their training in order to gain their certificate. Nurses who enter small. pox hospitals or volunteer as plague nurses do so with full knowledge of the risks they run. The ordinary well brought up girl of from 20 to 25, the usual age at which probationers enter hospitals, is ignorant of the existence of venereal disease and of the horrible consequences of contracting it, and certainly should not be exposed under compulsion and in ignorance to such a vile contagion. It has been said that students and doctors run the same risk. But young men are not brought up in ignorance of these diseases as their sisters are, and they are fully aware of their dangers; also the risk incurred in a daily visit to the wards and the performance of dressings and examinations with every precelution against infection is a very different one from that incurred by the nurse. For she has to live all day and every day from 7 in the morning to 9 at night (except for two off duty hours and meal times) in the offensive atmosphere of a 